\title{
Roles and Responsibilities of Notary in Deed Making Agreement on Sale and Purchase Agreement When the Parties Dispute
}

\begin{abstract}
Irfan Iskhak $^{\mathbf{1}}$, Hengki Irawan $^{2}$ and Aryani Witasari ${ }^{3}$
Abstract. Notary acts as a medium for the birth of a deed of authentic. Responsibility of notaries in the sale and purchase agreement to the party is limited to deed that made accordance with the authority of his post by UUJN. The purpose of this study are: 1 . to know the roles and responsibilities in the making notary deed of sale and purchase agreement in the event of disputes for the parties. 2. To determine the notary solution in preparation of deed sale and purchase agreement in order to avoid disputes of the parties.

Based on the results of data analysis concluded that: 1 . The responsibility of the notary deed merely on early part deed / deed chief, section final / concluding notarial deed and have full accountability of the contents either formal and material. 2. In the duty of notary shall apply precautionary principle and do legal education in order to avoid disputes in the future.

Keywords: Notary; Agreements; Sale and Purchase Agreement; Deed.
\end{abstract}

\section{Introduction}

Indonesia is a country that has a law in the constitutional function to protect against the human rights legal guarantee for enforcement demands through the process as fair as possible. The law provides for the state functions legal certainty for the community as a form of state protection. As the demands of legal protection in public life is doing commitments legal acts that agreement.

Guarantee certainty, public order and protection law, which cored the truth and justice in the traffic laws generally require decisive evidence with rights and responsibilities clearly a person as a subject in public law. ${ }^{4}$

The lives of people who need legal protection public services sector is now increasingly widespread with the increasing needs of the people on services. This impacted on the increase in the field of notary services. In this case the role of the notary in the services sector is as officials given authority by the state to serve the public in the field of civil particularly making authentic deed. As mentioned in Article 1 (1) of Act No. 2 of 2014 on changes in the Act No. 30 of 2004 concerning Notary, then called UUJN.

"Notary public officials who are authorized to make authentic deed and other powers referred to in this act".

Philosophical grounding establishment is the realization guarantee uujn rule of law, order and protection law that core truth and justice through the deed he had done, notary should provide to the community legal certainty notary service user. ${ }^{5}$

\footnotetext{
1 Studens Master of Notary Law, Sultan Agung Islamic University Semarang email boyyardimaria@gmail.com

2 Students of Master of Law, Faculty Of Law, Universitas Islam Sultan Agung email hengki.irawan45@yahoo.com

${ }^{3}$ Faculty of Law Universitas Islam Sultan Agung, Semarang.

${ }^{4}$ Sjaifurrachman, 2011, Aspek Pertanggung Jawaban Notaris dalam Pembuatan Akta, Mandar Maju, Jakarta, p. 7
} 
Products issued by the notary law is in the form of acts that have properties and have a strength of evidence authentic perfect. As the definition of authentic deed specified in article 1868 of the civil code: "An authentic deed is a deed which is in the form prescribed by the act, made by or in front of public employees in power to the place where the deed made". ${ }^{6}$

Evidence authentic deed as the strongest and fulfilled, very important role in any legal relations in public life. In a variety of business relationships, activities in the banking sector, land, social work, and others, which require proof written in the form of authentic deed, the development of demand for rule of law in a range of economic and social affairs, both at the level of regional, national, and global. Through authentic deed which clearly defines the rights and duties of the parties and ensure the rule of law and at the same time is also expected to avoid the occurrence of the dispute. Although the dispute can not be avoided, in the dispute resolution process, which is the authentic deeds written evidence strongest and real fullest who gave donations for the settlement of the case is inexpensive and quick.

However, a notary has a duty to contain provisions that what loaded in deed earnest understood and in accordance with the will of the parties, that is the way to read it, so that it becomes clear fill deed, as well as provide access to information, including access to regulation legislation related to the parties. Moreover, it can determine freely to approve or not approve content deed to be signed. ${ }^{7}$

In addition to providing security, public order and legal protection to the notary service user society, thus notary deserve notary supervision over the execution of tasks. The other side of the supervision of notaries are aspects of legal protection for notary in carrying out duties and functions that the law was given and entrusted to him, as mentioned in item preamble considering that a notary is certain positions that run profession in legal services to the people who need to get in order to achieve the protection and guarantee legal certainty.

The role of law in public life set has been known since the public know the law itself, the relationship between the community and law expressed by a very famous adage in legal studies are: ubi so cietes ibi ius (where there are people there is law). ${ }^{8}$ Legal action to prevent arbitrary performed by a notary or abusing the trust given by the people as a notary public, implementing the duties of the need for supervision, so that in the future parties concerned no one harmed.

Because the load acts in the law of 1 (one) deed of the purchase agreement commitments piece of land, it is detrimental to purchaser caused deed which is expected to give the order to the buyer legal certainty formal protected.

Based on the description and practice of making the deed of sale and purchase agreement the authors are interested in doing research with title "Roles and Responsibilities of Notary in Deed Making Agreement on Sale and Purchase Agreement When the Parties Dispute".

\footnotetext{
5 Biro Humas and HLN. Hasbullah, Notaris dan Jaminan Kepastian Hukum, (www.wawasanhukum.blogspot.com, 7 January 2019)

${ }^{6}$ Abdul Ghofur Anshori, 2009, Lembaga Kenotariatan Indonesia Perspektif Hukum dan Etika, UUI Press, Yogyakarta, p. 14

${ }^{7}$ Law on Notary, Act No. 22014 on amendment of Act No. 30 of 2004, LN No. TLN No. 117 4432, Psl.1 (1) p. 38-39

${ }^{8}$ Satjipto Raharjo, 1983, Masalah Penegakan Hukum, Sinar Baru, Bandung, p. 127
} 


\section{Research Method}

The method used in this research is a form of juridical-empirical (socio-legal research). Empirical legal research type is the type of research that analyzes a problem legal or legal issues based on a problem that exists in society itself by obtaining the field data ${ }^{9}$, fieldworkers (field research) or the empirical research was carried out with the starting point of primary data obtained place of study. ${ }^{10}$

Process analyst legal materials begins with reviewing all the available materials obtained from research data obtained directly from the source first to fall directly into the field to obtain data according to research that will be examined through interviews with parties related to the issues raised by researchers.

All material obtained in advance processed to give a picture as needed, and then analyzed using qualitative analysis methods, where the materials needed to address the issues, both primary products and secondary materials, collected and then selected, sorted by quality and relevance then determined the essential ingredients and materials that important to answer the problem.

\section{Results and Discussion}

\subsection{Roles And Responsibilities Of Notary In Deed Making Agreement On Sale And Purchase Agreement When The Parties Dispute}

Agreements sale and purchase made by notary is a authentic deed because it was made before official public ruling made as set forth in article 1868 of the civil code, which reads: "A authentic deed is a deed in the form prescribed by the act made by or public servants before the ruling to the place where the deed made ". ${ }^{11}$

According to Hans Kelsen, which describes a theory of liability in the law is a concept related to the Concept of Legal Liability (CSR) is a concept of Responsibility Law (Liability). Position or Profession in the Making Notary Deed is a trust that must be accounted Position either in law or in Professional Ethics. Notary deed made is the deed that is authentic, therefore notaries in making the deed must be carefull and always based on the regulation. ${ }^{12}$

In practice the sale and purchase agreement has been frequently used, but it turned against the sale and purchase agreement is only used general principles agreement stipulated in the civil code or in other words have not been regulated in the legislation relating to the land rights. In the sale and purchase made before a notary public, the deed of sale and purchase agreement into a deed of the authentic. it is enshrined in article 1868 of the civil code be seen that for authentic deeds of aktanya form prescribed by the act and must be made by or in front of the authorized officer.

\footnotetext{
${ }^{9}$ Amirudin and Zainal Asikin, 2010, Pengantar Metode Penelitian Hukum, Edisi 1, Rajawali Pers, Jakarta, p. 118

${ }^{10}$ Soerjono Soekamto, 1986, Faktor-Faktor yang Mempengaruhi Penegakan Hukum, Jakarta: CV. Rajawali, p. 5

${ }^{11}$ Subekti.R and Tjitrosudibio, 2001, Kitab Undang-undang Hukum Perdata, Pradnya Paramita, Jakarta, p. 475

${ }^{12}$ G. H. S. Lumbang Tobing, 2008, Peraturan Jabatan Notaris, $4^{\text {th }}$ Edition Erlangga, Jakarta, p. 51
} 
According to Abdul Kadir Muhammad Opinion, Notary running tasks and his post should be responsible, in the event that:

- Notary charged with making deed properly. This means that the deed made it fulfill the will of law and stakeholders demand for his post;

- Notary deed prosecuted produce quality. This means the deed he made in accordance with the rule of law and the will of interested parties in a real sense, not making it up. Notary explain to interested parties truth content and procedures deed he made it; and

- Positive impact, meaning that anyone will admit it has deed proof perfect strength.

Notaries in UUJN responsible for deed sale and purchase of the deed that made accordance with the authority of his post, responsibility for deed he made was in accordance with any one (1) duties and its authority set out in UUJN, and is not a problem as long as the deed sale and buy the purchaser already fulfill its obligations are sold to the sellers. Legal protection is to be given to the right of all parties in the fulfillment of the sale and purchase are already protected by the power law given authentic deeds, according grounded article 1338 of the civil code, the good intentions of the parties to fulfill the agreement that has been made. then it can be argued that the responsibility of the notary of the deed he made was sebatas in section early deed / head deed and section final / closing deed, in this section notaries have accountability, full of the contents either formal and material, on identities to notary accountable all supported by identity issued by other authorized officials, and the truth of the parties applicant comes to making the agreement, regarding whether or not there are witnesses, on the day, date and so on, as we mentioned it.

Notaries can not be requested responsibility towards losses incurred as a result of the creation or preparation and implementation deed along notary assistance provided has been implemented in accordance with the provisions UUJN, other legislation within the limits of reasonable accuracy.

The role of the notary merely as a medium for the birth of a deed of authentic when examined by normative. Notaries are not required in carrying out his post truth investigate task identity, truth content materially from deed and deed of authentic will be proof that the event has occurred or the relationship between the parties. As for sanctions, both civil law, administrative and criminal can not be applied to the Notary. Legal sanctions can be applied to applicant giving false information in the deed of sale and purchase agreement in the form of civil sanctions redress by the injured party or criminal sanctions in accordance formulation of criminal acts done pursuant to article 263 of the criminal code.

While the legal disputes element as if notaries in committing abuse their authority, given her existing powers have been abused, and eventually sodium absorption ratio in accordance with the aim of giving the authority itself, it is therefore not aplicate authority accordingly. The notary will be penalized administration, civil and criminal.

The parties concerned are doing binding purchase agreement what if there are parties who do citdra promise in the agreement is dependent upon the contents of the strength of the agreement, notary acts only make deed and responsible protect deed of agreement binding sale and purchase and no relation to the dispute.

Legal protection against the parties on the disputed deed binding sale and purchase when viewed from the aspect of civil law is in the form of filing civil lawsuits. Notary public officials who are involved in the process of making the deed can not necessarily 
involved disputes, because deed he made are in accordance with the procedures and an arbitrary task based UUJN. Meanwhile, when viewed from the aspect of criminal law, legal protection against the parties such was able to report any suspected criminal fraud under the provisions of article 378 of the criminal code.

\subsection{Notary Solution In Preparation Of Deed Sale And Purchase Agreement In Order To Avoid Disputes Of The Parties}

To prevent the occurrence of acts legal profession and notarial should guided subject to UUJN, as set in Article 16 UUJN As for the obligation to do the acting honestly, thoroughly, independently, impartially and safeguard the interests of those involved in the act of law. ${ }^{13}$ And obliged keeping all things relating to the deed and other securities is to protect the interests of all parties concerned. In realization of legal certainty security, public order and protection law that core truth and justice. Through the deed he had done, the notary must be able to provide certainty and legal protection to people who use notary services.

Notary in this case to protect job profession in order to avoid action against the law should apply the precautionary principle. Precautionary principle is a principle which states that a notary public in performing their duties and his position should be more careful. Implementation of the precautionary principle must be conducted in the preparation of this deed by:

- Doing introduction to applicant, based identity was shown to the Notary;

- Ask, then listen and watch on the desire or the will of the parties (question and answer);

- Letter examine evidence relating to the desire or the will of the Party;

- Provide advice and make Deed framework to meet the desire or the will of the parties;

- Meets every technique aministratif Notary deed, like reading, signing, provide copies, and filing for minuta; and

- Perform other obligations related to the implementation of the tasks Notary. ${ }^{14}$

In addition to running tasks and Notary job must do precautionary principle, among others:

- Notary Deed charged with acts properly. Deed made it fulfill the will of Justice and request the interested parties because His post;

- Notary Deed prosecuted produce quality. Deed which made it according to the rule of law and the will of the parties interested in the true sense. Notaries must explain to the parties concerned in the Truth Content and Procedures deed he made it; and

- Positive impact, meaning that anyone will admit it has Deed Proof Perfect Strength.

The importance of role of the notary in helping to create the rule of law as well as legal protection for the public is more preventative which is prevention of legal issues, by way of publishing authentic deed made in front associated with legal status, rights and

\footnotetext{
${ }^{13}$ Aryani Witasari, 2012, MPD bukan Advokat para Notaris berdasarkan Undang-undang No.30 Tahun 2004 tentang Jabatan Notaris, Jurnal Hukum, XXVIII (2): 888

${ }^{14}$ Philipus M. Hadjon,-dkk, 2002, Pengantar Hukum Administrasi Indonesia (Introduction To The Indonesia Administrative Law), Gadjah Mada University Press, Yogyakarta p. 270.
} 
obligations someone in law that serves as evidence of the most perfect in court in case of dispute over rights and obligations related. ${ }^{15}$

In the opinion of the Notary / PPAT Dr. Ngadino, SH, Sp.N., MH in Interview Writer July 31, 2019 located in the Office of Semarang said that: "In order to avoid disputes the Sale and Purchase Agreement are not paid deed should not be submitted to the Parties for the deed can be converted sale the other Party and the Notary, preferably stored in the Authorized Notary Office in accordance with the collective agreement." ${ }^{16}$ Notary in practice against the applicant in this case other than just implementing Its authority in accordance UUJN, which is set to Make in a form prescribed by UUJN, must have legal protection for himself and the Parties are facing so that in the future there is no dispute between the Parties, notary know applicant based identity shown to the notary that ID. To protect notary job must have its own specific documents to applicant that other agreement or recognition of the parties to ensure that in the future if there is a dispute fully borne by the parties in the agreement applicant.

\section{Closing}

\subsection{Conclusion}

- Accountability notary in the deed sale and purchase of the deed that made accordance with the authority of his position, which is based uujn it can be argued that the responsibility of the notary of the deed he made is limited to section initial deed / head deed and section final / closing deed, in this section notary has full accountability of the contents either formal and material. Notary role just as the media for the birth of a deed of authentic. Notaries are not required to run the task his post investigate identity truth, truth fill material of the deed and deed of authentic will be evidence that there have been events or relationship between the parties.

For the parties concerned who did binding purchase agreement if there are parties who do promise in the agreement is dependent upon the content power of the agreement, the dispute concerning the parties that occurred outside of the authority of the notary; and

- Notary on protect profession job order to avoid torts about a deed that degraded or any dispute in the future agreement, the notary must apply the precautionary principle. Precautionary principle is a principle which states that a notary public in carrying out tasks and his position should be more careful, and to protect notary job must have separate documents to applicant lodging that other agreement or recognition of the parties to ensure that in the future if there is a dispute fully borne by the parties in the agreement applicant.

\subsection{Suggestion}

- For notary as public official perform a task noble to help the public to an agreement sale and purchase agreement is required to always act carefully, carefully, and continued learning to increase knowledge of the profession to explore the legislation

\footnotetext{
${ }^{15}$ Sjaifurrachman and Habib Adjie, 2011, Aspek Pertanggungjawaban Notaris Dalam Pembuatan Akta, Mandar Maju, Bandung, p. 7.

${ }^{16}$ Interview with Notary / PPAT Dr. Ngadino., SH., Sp.N., MH Date 31 July 2019
} 
Volume 6 Issue 2, June 2019

applicable to both during the run his position as the notary, so as to minimize the occurrence of the act or deed that was born that his later disputed by the parties concerned;

- Notaries in creation deed sale and purchase agreement in addition to asking for documents first of the applicant, for sellers who have heirs if it can not be present with gave the power of attorney, the notary must make a statement minutes stating that the beneficiary is not biased attend and power of attorney made chop enough to at signed by parent selling and witnesses. This is to avoid disputes in the future, here notary've has strong evidence on delegation of authority to the parties on non hadiranya in the agreement;

- For SPA deed (Sale and Purchase Agreement) that have not been paid in full should not be given to the party but rather deposited at the notary office authorized by the joint agreement; and

- For notary in this millineal era should increase the knowledge in IT (Science and Technology) as well as a foreign language in the face of globalization in the field of technology.

\section{Bibliography}

\section{Book}

[1] Abdul Ghofur Anshori, 2009, Lembaga Kenotariatan Indonesia Perspektif Hukum dan Etika, Yogyakarta: UUI Press

[2] Amirudin and Zainal Asikin, 2010, Pengantar Metode Penelitian Hukum, Edisi 1, Jakarta: Rajawali Pers

[3] G. H. S. Lumbang Tobing, 2008, Peraturan Jabatan Notaris, Cetakan Keempat Erlangga, Jakarta.

[4] Philipus M. Hadjon,-dkk, 2002, Pengantar Hukum Administrasi Indonesia (Introduction to the Indonesia Administrative Law), Gadjah Mada University Press, Yogyakarta.

[5] Satjipto Raharjo, 1983, Masalah Penegakan Hukum, Sinar Baru, Bandung.

[6] Sjaifurrachman, 2011, Aspek Pertanggung Jawaban Notaris dalam Pembuatan Akta, Mandar Maju, Jakarta.

[7] _dan Habib Adjie, 2011, Aspek Pertanggungjawaban Notaris Dalam Pembuatan Akta, Mandar Maju, Bandung.

[8] Soerjono Soekamto, 1986, Faktor-Faktor yang Mempengaruhi Penegakan Hukum, CV. Rajawali, Jakarta.

[9] Subekti.R and Tjitrosudibio, 2001, Kitab Undang-undang Hukum Perdata, Pradnya Paramita, Jakarta.

\section{Legislation}

[1] The constitution of the Republic of Indonesia in 1945.

[2] Law of the Republic of Indonesia Number 2 of 2014 on the amendment of Act No. 30 of 2004 concerning Notary.

[3] Code of Civil law. 


\section{Journals}

[1] Aryani Witasari, 2012, MPD bukan Advokat para Notaris berdasarkan Undangundang No.30 Tahun 2004 tentang Jabatan Notaris, Jurnal Hukum, XXVIII (2)

\section{Internet}

[2] Biro Humas and HLN. Hasbullah, Notaris dan Jaminan Kepastian Hukum, (www.wawasanhukum.blogspot.com, 7 January 2019) 